\title{
紙の透気度測定法に関する研究
}

\author{
㩰科珍郎・竹下寬・武祐一郎**

\section{Studies on The Measurement Method of Porosity of Paper} \\ Yoshiro Warashina, Hiroshi Takeshita and Yuichiro Take \\ (Research Laboratory, Tomoegawa Paper Mfg. Co., Ltd.; Mochimune, Shizuoka City, Japan)
}

The measurement methods of paper by the porosity testers of six kinds, Gurley densometer, Emiel Greiner porositymeter, Schopper air permeahility meter, Emanueli porositymeter, Oken type denso-aspero meter and smoother, were examined, and further the relationships between these testers were theoretically and experimentally obtained.

(1) In the relation between the Gurley densometer $(G)$ and the Emiel Greiner porositymeter $(E)$, the theoretical formulas agreed well with the experimental values. But, in the range of low air resistance, the experimental values by the Emiel Greiner porositymeter were smaller than the theoretical ones, whereas in the range of high air resistance, that relation was reverse.

The relationship between two testers was shown by the following theoretical formulas.

$$
\begin{aligned}
& V_{e}=\frac{83046.6}{0.803 t_{G}+513.34} \cdots \cdots \ldots \ldots \ldots \ldots . . . \cdots(1) \\
& V_{E}=\frac{\left(979+0.675 V_{e}\right)}{1033} V_{e} \ldots \ldots \ldots \ldots \ldots(2) \\
& \text { were } V_{e} \text { and } V_{E} \text { in cc/5min } \\
& t_{G} \text { in sec } / 100 \mathrm{cc}
\end{aligned}
$$

(2) In the relation between the Schopper air permeability meter $(S)$ and the Gurley densometer or the Emiel Greiner porositymeter, the theoretical formulas agreed very well with the experimental values.

Especially, the theoretical formula of relation between the Schopper and the Gurley was in better agreement with the experimental values than that relation between the Emiel Greiner and the Gurley.

The relationship between the Schopper and the Gurley was shown by the following theoretical formula.

$$
\begin{aligned}
& t_{G}=\frac{24096.38}{V_{S}} \ldots \ldots . . . \\
& \text { were } t_{G} \text { in sec } / 100 \mathrm{cc} \\
& V_{S} \text { in cc/5min }
\end{aligned}
$$

(3) In the relation between the Emanueli porositymeter $(M)$ and the Gurley densometer, the theoretical formula also agreed well with the experimental values, and this formula was as follows.

$$
\begin{aligned}
& A_{M}=43.478 \times t_{G} / d \cdots \cdots \cdots \cdots \cdots \cdots \cdots \cdots \cdots(4) \\
& t_{G}=523.023 \times P_{1} / P_{2} \ldots \ldots \ldots \ldots \ldots \ldots \ldots \ldots \text { ( } 5 \text { ) } \\
& \text { were } A_{M} \text { in a unit of Emanueli } \\
& d \text { is thickness in } \mathrm{cm} \\
& t_{G} \text { in sec/ } 100 \mathrm{cc} \\
& P_{1} \text { or } P_{2} \text { is a different pressure }
\end{aligned}
$$

(4) The Oken type denso-asperometer $(O)$ and the Smoother $(S M)$ have close relation with usual tester as the Gurley densometer etc.

These testers were suitable for a manufacturing process test of high air resistance paper because these testers have superior accuracy and especially made the rapid test possible.

The relationship between the Gurley and the Smoother was shown by follows experimental formulas;

in the case which standard head was used,

$\log H_{S M}=-1.146 \log t_{G}+5.122 \cdots \cdots \cdots \cdot(6)$

in the case which cramp type head was used,

$$
\log H_{S m}=-0.638 \log t_{G}+4.247 \cdots \cdots(7)
$$

The relationship between the Gurley densometer and the Oken type denso-aspero meter was shown by the following experimental formula,

$\log T_{o}=0.965 \log t_{G}+0.0818$

* 源稿受付 37.4 .11 (当協会第 9 回研究発表会䛾演)

** 巴川製紙・技術研究所 


\section{I 緒}

言

紙の透父度（Porosity，Air permeability）または 父密度 (Air resistance, Air impermeability) は極め て重要な紙の性質であり，筆記用紙，印刷用紙におい てはインクの吸収に関係があり，さらに Saturating paper，電気絶緣綎のように合成樹脂または油を含浸 させて使用する場合などに拉いては特汇重視される性 質であることが一般に認められている11。

また絓の透気度は絓の製造条件，特にパルプの叫解 状態と密接な関係があること怯周知のことであり，こ れに関する䂨究毛報告されている2)。

このように透気度または気密度は，䋊として極めて 重要な特性であるが，これが湘定には各種の試験器が 用いられて扔り，これらの間で測定值の表現に統一が なく，また試琴器によっては测定範用に制限が存在す るものもある。

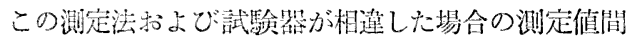
の関係について今まで数名の人によって報告3745)され ているが，必ずしも十分なものではない。

本報に拈いて虫，ガーレーデンソメータ；エミルグ ライナーポロシテメータ, ショッパー式透気度試験器, エマニュエリーポロシテメータ, 王研式透気度試験器

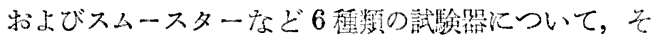
れぞれの测定法ならびに各湘定器間の関係学实测值と 理諭值の雨面から娭䚯した。

また透父度試験器の精度および器差の倹定などの槽 準試料として，大抵の場合絓が用いられて来たが，こ れにはいろいろと間題があるので，金属の祭集板を作 製し，これについての検討結果も瓶觖した。

\section{II 各測定器間の相互関係}

まず，ガーレーデンソメーターを基準としてエミル グライナーポロシテメータ, ショッパー式透父度試娩 器およびェマニニエリーポロシテメータの相互関係を 求めた。

\section{（1）実 験 方 法}

i) 湘 定 試 料

测定誡料としては後述する金属の標準板が咠も望ま しいが，高気密度紙に相当する毛細管の入手が因難で あり，4程類の湖定器間の相互哭係としては比較的高 父密度範围に拈りる閭係を求めることを主限としたの でやさなく緍圭便用した。

ガーレーとエミルグライナーの関係ではエミルグラ イナー実测值で 5〜 65cc/min の間を 16 段階に，ガー レーとショッパー秥よびェミルグライナーとショッパ
一の関係ではショッパー寒測值で 0.5〜35cc の間を21 段階に，またガーレーとエマニュエリーの関係ではエ マニニエリー圧力比で 0.1〜55の間を50段階に分け られるような試料を選択した。

これらの試料のすべてを大きさ約 $80 \times 130 \mathrm{~mm}$ に切 断し，標準状態の中で十分に前処理を行ない，同一䇢 所を湘定して比較值を求めた。

ii) 测定 万 法

a）エミルグライナー测定法

第 1 四に湘定器の構造を示した。あらかじめ用意し た試料に直径 $25.4 \mathrm{~mm}$ の円を鉛筆で薄く記入し，試料 締付板の円孔にあわせて均等に締めつける。次にコッ クを閉じ，ビンを下部支持環に移し、コックを開くと

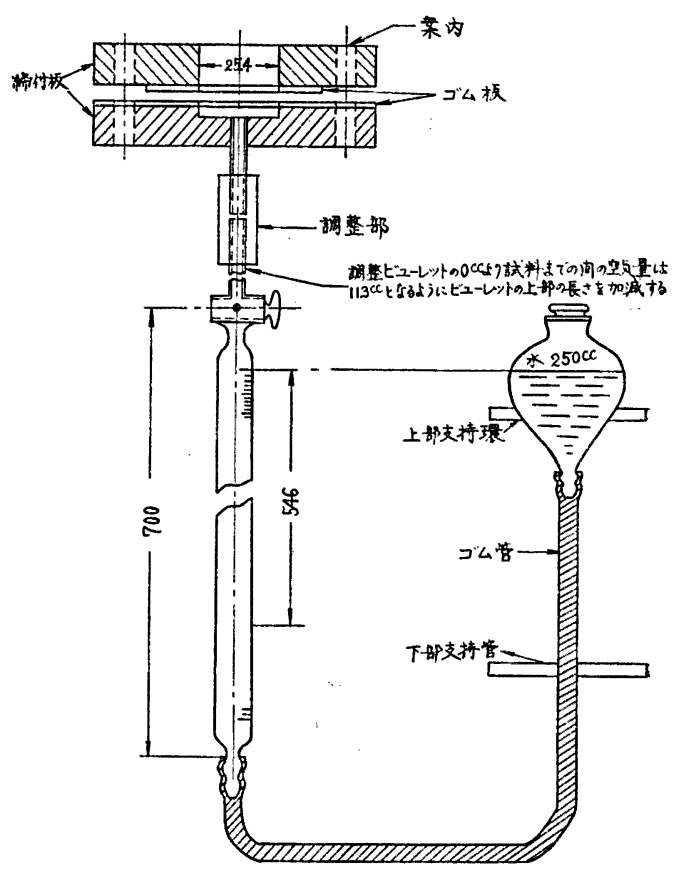

第1図エミルグライナーポロシテメータ（単位 $\mathrm{mm}$ ) 同時にストップウォッチを押し，5分間経過した後コ ックを閉じ，ビンを下部支持環から外してビン内の水 面とビュレット内の水面を一致させた後, 空気の透過 量（cc）を読み，最初にコックを開いた腷間に急激に 水面が低下することに関する補正值 0.8cc を引さ透気 度とした。この時の単位は $\mathrm{cc} / 5 \mathrm{~min}$ である。 $\mathrm{JIS}^{6)} に$ おいては，気密な物質の薄片をはさんで同様な操作を 行なった場合の読みを差引いて透気度とすると記され ており，これは補正值 $0.8 \mathrm{cc}$ に相当するものであり， これに関しては次に理論的検討を行なうう。

b) ガーレー気密度測定法 
$567 \mathrm{~g}$ の重量を持った内筒の試料締付部に，エミル グライナーで剆定した試料を挿入して均等に締付ける。 この場合，鉛筆て薄く記入した直径 $25.4 \mathrm{~mm}$ の丸印が， ガーレーの円孔（值径 $28.78 \mathrm{~mm}$ ）に同心円になるよう にする。他の操作は $\mathrm{JIS}^{6\rangle}$ に従い, $100 \mathrm{cc}$ の空気が透 渦するに要する時間を測定した。

c) ショッパー透気度測定法

第 2 図に測定器の構造を示した。試料台 (e) のガス ケット円孔 $(28.78 \mathrm{~mm})$ に，エミルグライナーで測定

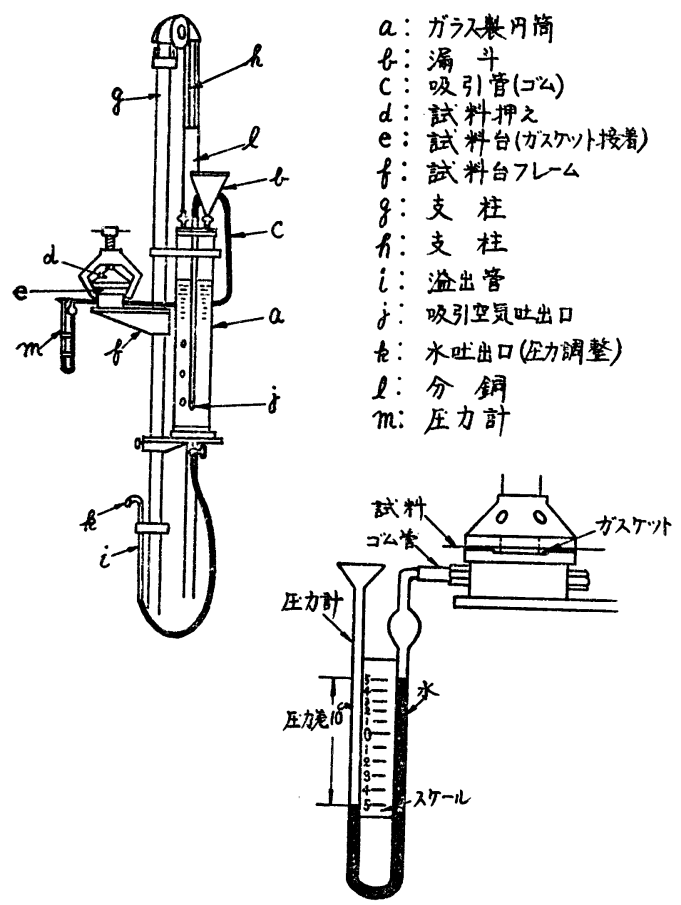

第 2 図 ショッパー式透気度測定器

した試料を丸印が同心円になるように挿入して締付け る。次陚料台フレーム (f) を徐々に上昇させて在力 計 $(\mathrm{m})$ の水柱の差が $100 \mathrm{~mm}$ になった時支柱 $(\mathrm{g})$ に固 定する。このことによって $e$ 就よび吸引管 (c) は 100 $\mathrm{mm}$ の減圧となり, 外部の空気は陚料を通過して $e$ に 入り， c, j を経てガラス製円筒 (a) 内の上部空間に入 る。これと同時に浸入した空気と等量の水が渪出管 （i）を径て水吐出口（k）から流出し，所属するメスシ リンダーに集められる。5 分間経過した後にコックを 閉じメスシリンダー内の水量（cc）を読み透気度とし た。この時の単位は cc/5min である。

d) エマニニエリー不透過度 (気密度) 湘定法

空気は紙を通過する際にその圧力が低下する。この 場合空気の通過が困難な紙の場合ほど圧力の低下もま た大となる。この原理を応用したものがエマニュエリ
一測定器である。本測定器の主要部の桙造は第 3 図の 通りである。

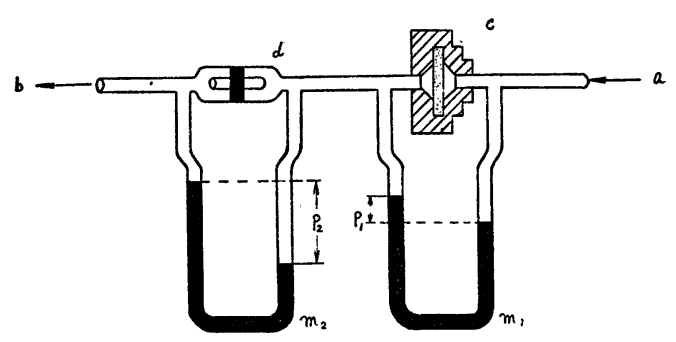

第3図 エマニニエリー不透過度試験器の原理

圧搾空気をaから入れ，試料 (c) 占よび標準毛細管 （d）を経てbから排出させる。 $c$ および $d$ を通過する 前後におけ空気压力 $P_{1}, P_{2}$ を夫々圧力計 $\left(m_{1}, m_{2}\right)$ にて㜔む。 $d$ は試料に刘して標潐となるべきもので， 絓質に応じて適当な直径のものを選ぶ。得られた $P_{1}$, $P_{2}$ を次式代代入し気密度を求める。

$$
A \cdot d=K \frac{P_{1}}{P_{2}} \cdot S
$$

ここに $A$ : 気密度

$$
d \text {; 絟の厚サ }
$$

\section{$S:$ 試料の空気透過面䅡}

$K$; 測定器による定数

\section{(2) 理 論}

有效面積 $S\left(\mathrm{~cm}^{2}\right)$ ，厚サ $d(\mathrm{~cm})$ なる紙の両側にお ける圧力差を $P$ とし, 時間 $t$ (秒) にこの紙を通過ず る父体（一般的汇空気, 粘性係数 $\eta$ ) の量 $V\left(\mathrm{~cm}^{3}\right)$ は次式によって示される。

$$
V=\frac{P S t}{A \eta d}
$$

ここに，Aは紙によって定まる定数で透過係数と言 ら。

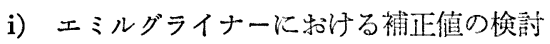

測定法のところで述べたように，観測値から $0.8 \mathrm{cc}$ の補正值を差引いた值を透父度の実測值としたが，こ の值は, 試料を締付计た時, ビンを下部支持環に移し た時および最初にコックを開いた脟間の夫々にビニレ ット内の水面が低下することに關するものであり, $\mathrm{JIS}^{6)}$ の場合に最後に钼測值より差引く值に相当する ものである。

まず，試料を締付けた時の水面の低下であるが，こ れは縍付板のゴム板が圧縮されること妨よび締付方式. 装置の構造によるものであり理論的取报いは困難なの で実測値 $(0.15 \mathrm{cc})$ をそのまま用いることにした。

ビンを下部支持台に下げた時の水面の低下 $\left(\Delta h_{1}\right)$ を まず求めてみる。必要な略图を第 4 図淿した。 


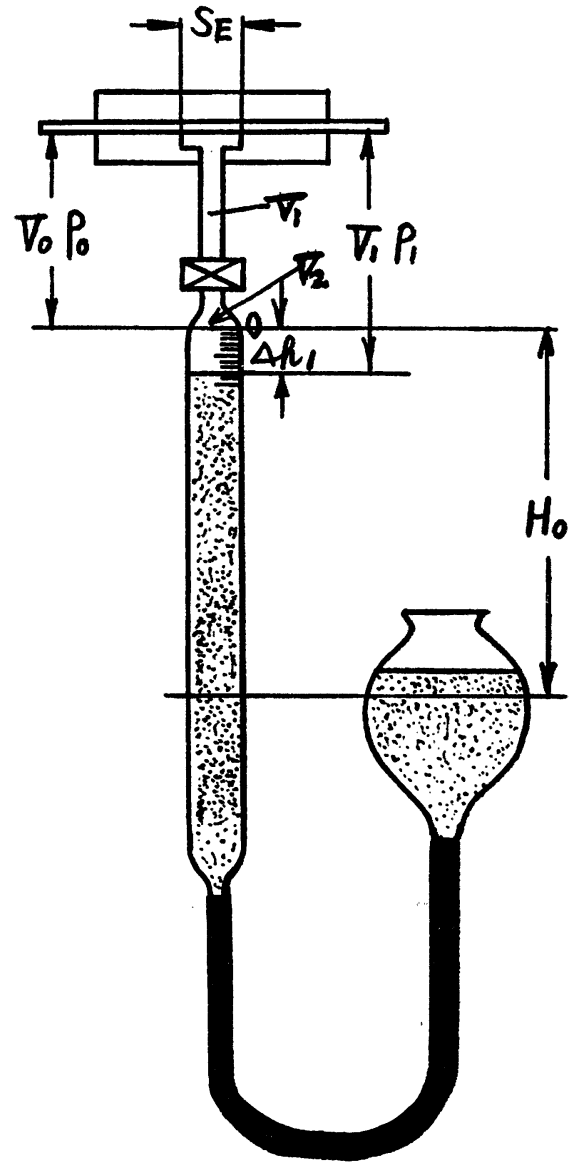

第 4 図

大気压を $P_{1}$ (1 気任とする） とする。ビンとビュ レットの水面が一致している時には，コックを閉じた 後に沶いても $V_{1}, V_{2}$ 内の生力は $P_{1}$ である。次にビ ンを下部支持台に下げるとビュレット内の水面は $\Delta h_{1}$ だけ低下し生力は $P_{2}$ に低下するので次の関係が得ら れる。

$$
\begin{aligned}
& P_{2}+\left(H_{0}-\Delta h_{1}\right)=P_{1} \\
& P_{1} V_{1}=P_{2}\left(V_{2}+a \Delta h_{1}\right)
\end{aligned}
$$

但し， $a$ はビェレットの内部断面積

(3) 式を変形すると $P_{2}=P_{1}-\left(H_{0}-\Delta h_{1}\right) \cdots\left(3^{\prime}\right)$ となり，これを（4）式に代入して整理すると，

$$
\begin{aligned}
a\left(\Delta h_{1}\right)^{2}+\Delta h_{1}\left[V_{2}+a\left(P_{1}-H_{0}\right)\right] & -H_{0} V_{2} \\
& =0 \cdots \cdots(5)
\end{aligned}
$$

湘定器の規定および測定器についての实湘值によると, $V_{2}=1.4 \mathrm{cc}, P_{1}=1033.6 \mathrm{~cm}$ (水柱に換算) , $H_{0}=54.6 \mathrm{~cm}$, $a=1.528 \mathrm{cc}$, となり，これらの值を（5）式に入れて 計算すると,

$$
\Delta h_{1}=0.073 \mathrm{~cm} \text { となる。よって } a \Delta h_{1}=0.11 \mathrm{cc}
$$

次にコックを開けた僢間の水面の低下 $\left(\Delta h_{2}\right)$ を求め る。この場合試料としては完全に空気を通さない薄片 が挿入さていると考える。コックを開けた瞬間のビ ニレット内の気任を $P_{3}$ とする。

$$
P_{3}+\left(H-\Delta h_{1}-\Delta h_{2}\right)=P_{1}
$$

コックを開ける前の $V_{1}$ および $V_{2}+a \Delta h_{1}$ 中の気圧は 夫々 $P_{1}, P_{2}$ であったから，

$$
\begin{aligned}
P_{3}\left[V_{1}+V_{2}\right. & \left.+a\left(\Delta h_{1}+\Delta h_{2}\right)\right] \\
& =P_{1} V_{1}+P_{2}\left(V_{2}+a \Delta h_{1}\right) .
\end{aligned}
$$

が求められる。しかして(4)の関係を(7)に入れれば, $P_{3}\left[V_{1}+V_{2}+a\left(\Delta h_{1}+\Delta h_{2}\right)\right]$

$$
=P_{1} V_{1}+P_{1} V_{2}
$$

(6) 式の $P_{3}$ の関係を（8）に入れ整理すると次の ようになる。

$$
\begin{aligned}
& a\left(\Delta h_{2}\right)^{2}+\Delta h_{2}\left[\left(V_{1}+V_{2}\right)+a\left(P_{1}-H_{0}\right.\right. \\
& \left.\left.+2 \Delta h_{1}\right)\right]-\left[H_{0}\left(V_{1}+V_{2}+a \Delta h_{1}\right)\right. \\
& \left.-\Delta h_{1}\left(V_{1}+V_{2}+a P_{1}+a \Delta h_{1}\right)\right]=0 \quad \ldots
\end{aligned}
$$

この式に测定器の規定および実測により次の值を代入 して $\Delta h_{2}$ を求める。 $\left(V_{1}+V_{2}\right)=11.3 \mathrm{cc}, \Delta h_{1}=0.073 \mathrm{~cm}, a=1.528 \mathrm{cc}$, $H_{0}=54.6 \mathrm{~cm}, P_{1}=1033.6 \mathrm{~cm}$,

$$
\Delta h_{2}=0.337 \mathrm{~cm} \text { よって } a \Delta h_{2}=0.515 \mathrm{cc}
$$

結局 $\Delta h_{1}+\Delta h_{2}=0.41 \mathrm{~cm}$ だけ水面が下ったことに なる。この容積 $a\left(\Delta h_{1}+\Delta h_{2}\right)=0.665 \mathrm{cc}$ が得られた。 但し，これは大気圧 $P_{3}$ の空気の容積であり，実際に は大気俚 $P_{1}$ に相当する空気の容積を求めなけ机ばな らない。匤力 $P_{3}$ で $a\left(\Delta h_{1}+\Delta h_{2}\right)$ の容積が开力 $P_{1}$ で $V_{x}$ になったとすると次の関係が得られる。

$$
P_{3}\left[V_{2}+a\left(\Delta h_{1}+\Delta h_{2}\right)\right]=P_{1}\left(V_{2}+V_{x}\right)
$$

(6) 式の $P_{3}$ の関係を代入し，さらに夫々の值を入 れると $V_{x}=0.52 \mathrm{cc}$ の值が得られる。

ところが，先に述べたよらに試料を締付けた時の水 面の低下が約 0.15cc あるので観测做から差引く值と してはこれを加えた 0.67ccでなければならない。 一方， JIS ${ }^{6)}$ にも示されているように，絓にセロフ ァンをはりつけた空気を通さない試片について実測し たところ $0.8 \mathrm{cc}$ の值が得られ，理諭的に求めた $0.67 \mathrm{cc}$ と非常に近い值いであり，計算に便利なように，この 実測值 $0.8 \mathrm{cc}$ を採用した。

ii）エミルグライナーとガーレーの関係

a) エミルグライナーの理論式（以下 $E$ の記号を 用いる)

必要な略図を第 5 図に示した。いま(2)式における $1 / A \eta d=k^{\prime} \quad S=S_{E} \quad k^{\prime} S_{E}=K \quad$ とすれば,

(2) 式は $V=K P t$.

ここで $P$ が一定であれば間題は簡単であるがエミ 


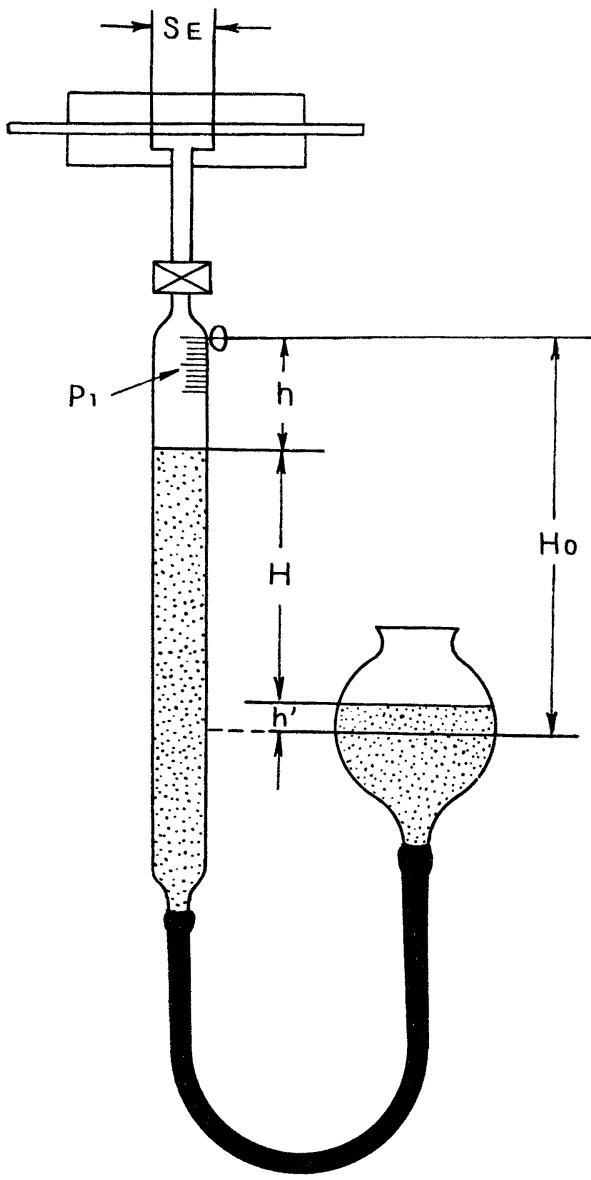

第 5 図

ルグライナーの場合は時間に対して指数函数的に変化 する。第 5 図に执いて $t$ 秒後注水面が 0 から $h \mathrm{~cm}$ だけ落下したとする。ビュレット内の水面が $h$ だけ 下がったことにより水準ビン内の水面が $h^{\prime}$ だけ高く なったとする。ビュレット抢よび水準ビンの内部断面 積を夫々，a，b（但し水準ビンの形は図の如く一定で ないが，この場合最大の面積を取ることにした。）と すれば，时間 $t$ に执忬る压力差 $P$ 法次のようにな る。

$$
P=H=H_{0}-\left(1+\frac{a}{b}\right) h
$$

次に $a h=V_{e}$ とすれば

$$
P=H_{0}-\left(\frac{1}{a}+\frac{1}{b}\right) V_{e} \equiv H_{0}-B V_{e}
$$

となる。但し $B=\left(\frac{1}{a}+\frac{1}{b}\right)$

$P$ は㛜密には指数函数的湾化するものであるが， 試料の気密度が大きく，時間が5 分程度である場合に は，Pの変化を時間に対して直線的に変化すると見て
も余り大きな誤差はなく，かつ計算を簡易化するため に直線的湾化するものと仮定して計算することにし た。

$t=0$ の場合は $P=H_{0}, t=t$ の場合は (13) 式のよ うになる。 $t$ 時間内に試料を通過する空気の容積を求 めるには压力が $t=0$ と $t=t$ の圧力の平均值で一定 であると見なしても差支えない。

$$
P_{m}=\left(P_{t=0}+P_{t=t}\right) / 2=H_{0}-\frac{B}{2}-V_{e}
$$

(14) 式の $P_{m}$ を(11) 式の $P$ に代入し， $V$ を $V_{e}, t$ を $t_{E}$ と書けば,

$$
\begin{aligned}
& V_{e}=K\left(H_{0}-\frac{B}{2}-V_{e}\right) t_{E} \\
\therefore \quad & V_{e}=\frac{2 K H_{o} t_{E}}{2+B K t_{E}} \ldots \ldots . . . . . \\
& K=k^{\prime} S_{E} \text { であるから }
\end{aligned}
$$

$$
V_{e}=\frac{2 k^{\prime} S_{E} H_{o} t_{E}}{2+B k^{\prime} S_{E} t_{E}}
$$

この $V_{e}$ は透過空気量として採用出来る値ではなく， $t_{E}$ (5 分) 経過してコックを閉じた時の空気の占める 容積であり，大気圧 $\left(P_{1}\right)$ より稀薄になっている。こ の化力を $P_{a}$ とすれば

$$
P_{a}+H=P_{1}
$$

また $\quad P_{a} V_{e}=P_{1} V_{E} \cdots \cdots(19) \quad$ であるからこの 両者の式から透過空気量が求められる。

$$
V_{E}=\left(\frac{P_{1}-H_{0}+B V_{e}}{P_{1}}\right) V_{e}
$$

b) ガーレーの理諭式（以下 $G$ の記号を用いる）

(2) 式に拈ける $1 / A \eta d=k^{\prime}$ ，とすれば $V_{G}=k^{\prime} S_{G} P_{G} t_{G} \cdots \cdots$ (21) となる。

この場合, $P_{G}$ は円筒の重量を円筒の外面積で割っ たものである。また $V_{G}$ は $100 \mathrm{cc}$ を規準にしてある。

c） ガーレーとエミルグライナーの関係

(21) 式より $k^{\prime}$ の関係を求め（17）式代入する 之次のようになる。

$$
V_{e}=\frac{2 S_{E} H_{o} t_{E} V_{G}}{2 S_{G} P_{G} t_{G}+B S_{E} t_{E} V_{G}}
$$

この（22）式を（20）式に代入すれば，エミルグラ イナーとガーレーの関係が求められるわけであるが,

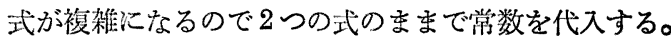

$S_{G}=6.45 \mathrm{~cm}^{2}, \quad P_{G}=12.45 \mathrm{~g} / \mathrm{cm}^{2}, \quad V_{G}=100 \mathrm{~cm}^{3}$, $t_{E}=300 \mathrm{sec}, \quad B=\frac{1}{1.528}+\frac{1}{60.0}=0.67 \mathrm{~cm}^{-2}, \quad H_{o}=$ $54.6 \mathrm{~cm}, S_{E}=5.07 \mathrm{~cm}^{2}$

$$
\begin{aligned}
\therefore V_{e} & =\frac{83046.6}{0.803 t_{G}+513.34} \cdots \\
V_{E} & =\frac{\left(979+0.675 V_{e}\right)}{1033} V_{e}
\end{aligned}
$$

iii） ショッパーとガーレーの関係

ショッパーの理論式は (2) 式より次の関係が求め 
られる。 $1 / k^{\prime}=A \eta d \equiv \frac{S_{S} P_{S}}{V_{S}} t_{S}$

ショッパーに関しては以下 $S$ の記号を用いる。

(25) 式と (21) 式とから

$$
t_{G}=\frac{P_{S} \cdot S_{S} \cdot t_{S} \cdot V_{G}}{S_{G} \cdot P_{G}} \frac{1}{V_{S}} \cdots \cdots(26) \quad \text { の関係か }
$$

得られる。

これに $t_{S}=300 \mathrm{sec}, P_{S}=10 \mathrm{~g} / \mathrm{cm}^{2}, \quad S_{S}=6.45 \mathrm{~cm}^{2}$ 岕よび先に示したガーレーにおける常数を代入すると，

$$
t_{G}=\frac{24096.384}{V_{S}} \cdots \cdot \cdots(27) \text { の関係が得られる。 }
$$

iv） ショッパーとエミルグライナーの関係

（25）式を(17) 式に代入し，夫々の常数を入れて 整理すると $V_{c}=\frac{166093.2 V_{S}}{38700+1026.675}$

の関係が得ら礼この式と（24）式とより両者の関係が 求められる。

v) エマニニエリーとガーレーの関係

第 3 図に和いて，試料执よび標準毛細管を通過する 空父量を夫及 $V_{1}, V_{2}$ とす礼ば次の上うになる。

$$
\begin{aligned}
V_{1} & =\frac{P_{1} S}{A \eta d} t \\
V_{2} & =\frac{P_{2} \pi r^{4}}{8 \eta L} t
\end{aligned}
$$

$V_{1}$ と $V_{2}$ とは相等しいものであるから (29) (30) 両式から先に示した（1）式が求めら机る。

以下エマニュエリーの記昘として $M$ を用いる。

まず，ガーレー父密度をエマニュエリー単位に換算 する式を求めてみる。（2）式を次のように変形する。

$$
A=\frac{P_{G} S_{G_{-}}}{r_{i} d V_{G}}
$$

これにガーレーの常数を入れると次の式が求められ る。

$$
A=4.3478 \times 10^{6} \times \frac{t_{G}}{d}
$$

但し，この $A$ は絶対単位でありエマニュエリー単 位は絶対単位の $10^{5}$ を实用単位としているので

$$
A_{M}=4.3478 \times 10 \times \frac{t_{G}}{d} .
$$

一方, エマニニエリーの式は

$$
A_{M}=K \times \frac{P_{1}}{P_{2}} \times \frac{1}{d} \cdots \cdots \cdots \cdots . . .(34) \text { であり， }
$$

この場合

$K=227400$ と定められたものを使用し， $d$ は mm の组を入礼ることになっている。

(33) と (34) 式より次の関係が得ら礼る。

$$
t_{G}=523.023 \times \frac{P_{1}}{P_{2}}
$$

\section{（3）実験結果および考察}

先に求めた理諭的な関係が，どの呈度実測值にあっ

\begin{tabular}{|c|c|c|}
\hline \multirow{2}{*}{$\begin{array}{c}\text { ガーレ一奏澌值 } \\
(\mathrm{sec} / 100 \mathrm{cc})\end{array}$} & \multicolumn{2}{|c|}{ エミルグライナー $(\mathrm{cc} / 5$ 分 $)$} \\
\hline & 実 测 值 & 理 論 值 \\
\hline 758.4 & 65.76 & 73.70 \\
\hline 817.6 & 64.10 & 70.57 \\
\hline 978.2 & 59.88 & 63.27 \\
\hline $1,186.8$ & 54.48 & 55.77 \\
\hline $1,307.2$ & 50.52 & 52.20 \\
\hline $1,558.0$ & 45.76 & 46.05 \\
\hline $1,912.8$ & 40.64 & 39.48 \\
\hline $2,250.8$ & 35.72 & 34.75 \\
\hline $2,496.8$ & 30.74 & 31.95 \\
\hline $3,334.0$ & 24.90 & 25.11 \\
\hline $4,336.8$ & 19.96 & 20.95 \\
\hline $6,079.2$ & 15.28 & 14.74 \\
\hline $8,771.8$ & 10.16 & 10.49 \\
\hline $12,470.0$ & 8.30 & 7.52 \\
\hline $15,360.0$ & 6.70 & 6.15 \\
\hline 20.656 .0 & 5.12 & 4.62 \\
\hline
\end{tabular}

ているかを検討した。

i) ガーレーとェミルグライナーの関係

ガーレ一值を規準にし，エミルグライナーの実測值 および（23）(24）式より求めた理論值を第 1 表および 第 6 図に示した。実测值と理論值とはよく一致してい るが，父密度の低い（ガーレ一值の小さい）ところで はエミルグライナーの理諭值は実測值よりも大さな数

第1表 ガーレーとエミルグライナーの関係

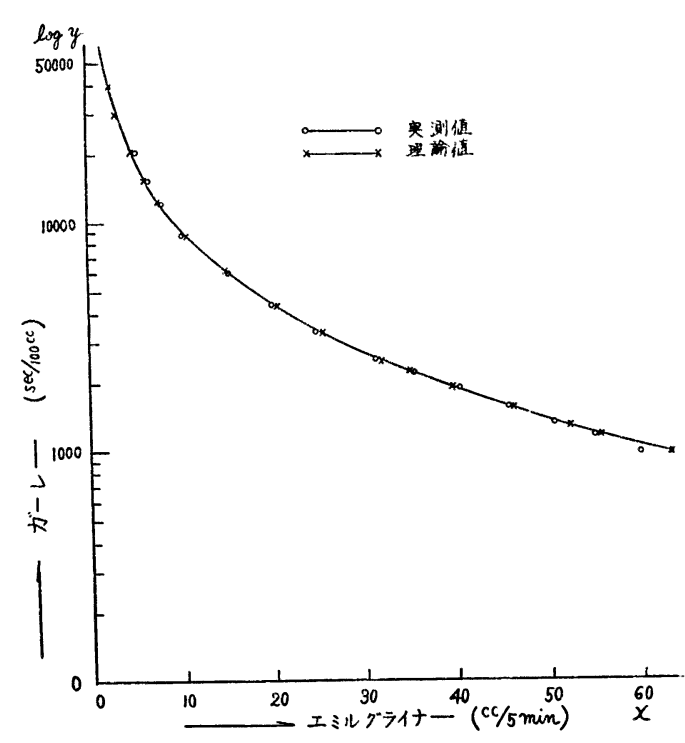

第6図 ガーレー，エミルグライナーの

実测值之理諭値の比較 
第2表 ショッパーとガーレーおよび エミルグライナーの関倸

\begin{tabular}{|c|c|c|c|c|}
\hline \multirow{2}{*}{ 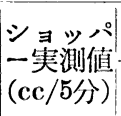 } & \multicolumn{2}{|c|}{${ }^{カ 3}-\begin{array}{c}\nu \\
(\sec / 100 \mathrm{cc})\end{array}$} & \multicolumn{2}{|c|}{$\begin{array}{c}\text { エミルグライナー } \\
(\mathrm{cc} / 5 \text { 分 })\end{array}$} \\
\hline & 奏 测 值 & 理 論 值 & 実湘值 & 理諭值 \\
\hline 0.5 & $49,180.0$ & $48,192.0$ & 2.0 & 2.01 \\
\hline 1.0 & $24,588.0$ & $24,096.4$ & 3.9 & 3.97 \\
\hline 1.5 & $16,280.0$ & $16,064.2$ & 5.7 & 5.89 \\
\hline 2.0 & $12,357.0$ & $12,048.2$ & 7.7 & 7.77 \\
\hline 3.0 & $8,050.0$ & $8,032.1$ & 11.3 & 11.39 \\
\hline 3.5 & $6,787.0$ & $6,884.7$ & 13.4 & 13.15 \\
\hline 4.0 & $6,030.0$ & $6,024.1$ & 14.7 & 14.87 \\
\hline 5.0 & $4,634.0$ & $4,819.2$ & 18.4 & 18.19 \\
\hline 6.0 & $4,084.0$ & $4,016.1$ & 22.5 & 21.31 \\
\hline 7.0 & $3,398.0$ & $3,442.3$ & 25.8 & 24.43 \\
\hline 8.0 & $3,010.0$ & $3,012.1$ & 27.6 & 27.37 \\
\hline 9.0 & $2,680.0$ & $2,677.4$ & 31.5 & 30.19 \\
\hline 10.0 & $2,386.0$ & $2,409.6$ & 33.5 & 32.90 \\
\hline 13.0 & $1,860.0$ & $1,853.6$ & 40.5 & 40.44 \\
\hline 15.0 & $1,650.0$ & $1,606.4$ & 43.5 & 45.03 \\
\hline 17.0 & $1,450.0$ & $1,417.4$ & 47.9 & 49.31 \\
\hline 20.0 & $1,210.0$ & $1,204.8$ & 52.9 & 55.20 \\
\hline 25.0 & 972.0 & 963.9 & 62.1 & 63.86 \\
\hline 28.0 & 870.4 & 860.6 & 65.5 & 68.00 \\
\hline 30.0 & 815.5 & 803.2 & 67.2 & 71.31 \\
\hline 35.0 & 698.4 & 688.5 & 74.5 & 77.67 \\
\hline
\end{tabular}

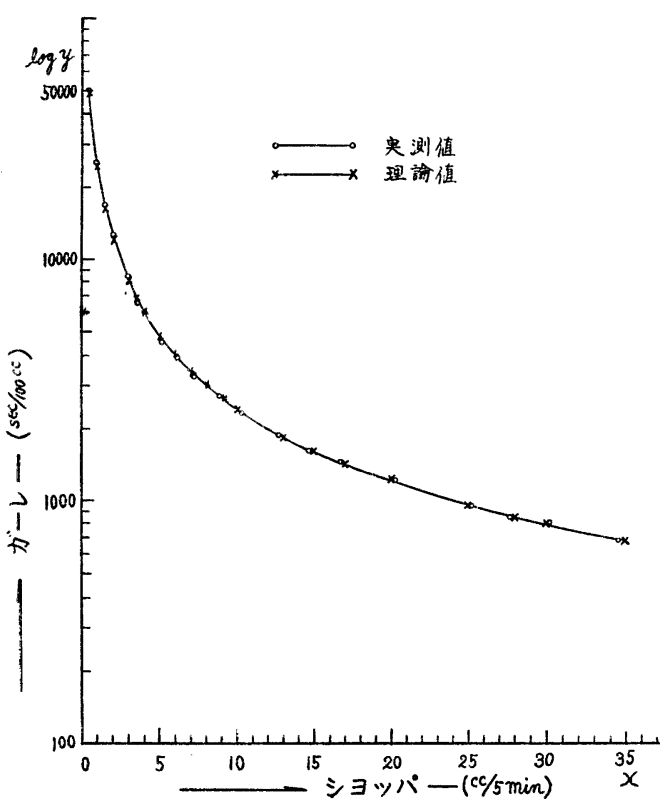

第7图 ガーレー,ショッパーの 実測值と理論值の比較

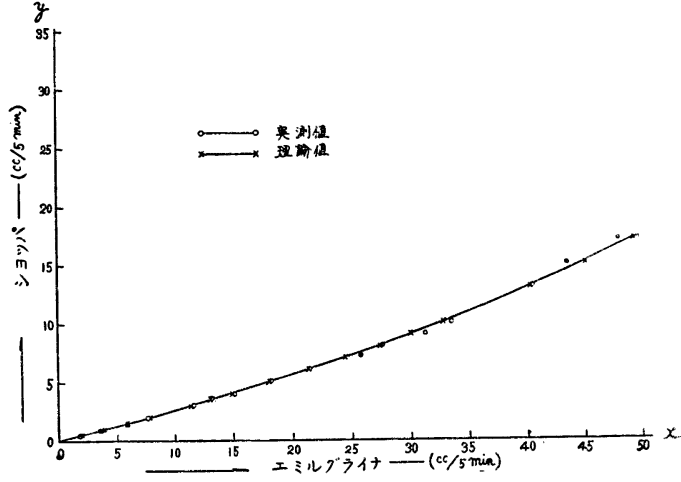

第8図 エミルグライナー，ショッパーの 実測值之理諭値の比較

第3表 ガーレーとエマニュエリーの関係

\begin{tabular}{|c|c|c|c|c|}
\hline \multirow{2}{*}{$\begin{array}{l}\text { ガーレー } \\
\text { 実 湘 值 } \\
(\mathrm{sec} / \\
100 \mathrm{cc})\end{array}$} & \multirow{2}{*}{$\begin{array}{l}\text { 王力比 } \\
\left(P_{1} / P_{2}\right)\end{array}$} & \multirow{2}{*}{$\begin{array}{c}\text { 厚 サ } \\
(\mathrm{mm})\end{array}$} & \multicolumn{2}{|c|}{$\begin{array}{l}\text { エマ=ラエリー } \\
\left.\text { (E.U. } 1 \times 10^{5}\right)\end{array}$} \\
\hline & & & 実 湘 值 & 理 論 値 \\
\hline 48 & 0.092 & 0.130 & 1.61 & 1.61 \\
\hline 124 & 0.233 & 0.110 & 4.82 & 4.90 \\
\hline 172 & 0.323 & 0.105 & 6.38 & 7.12 \\
\hline 478 & 0.876 & 0.130 & 15.32 & 15.98 \\
\hline 515 & 0.986 & 0.115 & 19.49 & 19.48 \\
\hline 642 & 1.324 & 0.071 & 42.40 & 39.31 \\
\hline 736 & 1.396 & 0.110 & 28.86 & 29.09 \\
\hline 888 & 1.687 & 0.117 & 32.79 & 32.99 \\
\hline 970 & 1.848 & 0.075 & 56.03 & 56.23 \\
\hline 1,074 & 1.974 & 0.075 & 59.85 & 62.26 \\
\hline 1,188 & 2.184 & 0.070 & 70.95 & 73.78 \\
\hline 1,396 & 2.726 & 0.072 & 86.09 & 84.29 \\
\hline 1,550 & 2.919 & 0.108 & 61.46 & 62.39 \\
\hline 1,672 & 3.271 & 0.073 & 101.89 & 99.58 \\
\hline 1,780 & 3.367 & 0.073 & 104.88 & 106.00 \\
\hline 2,100 & 4.217 & 0.109 & 87.98 & 83.76 \\
\hline 2,550 & 4.826 & 0.105 & 104.52 & 105.59 \\
\hline 3,100 & 5.778 & 0.058 & 226.53 & 232.37 \\
\hline 4,250 & 8.769 & 0.078 & 255.64 & 236.89 \\
\hline 5,400 & 10.522 & 0.062 & 385.92 & 378.68 \\
\hline 6,700 & 13.188 & 0.062 & 483.70 & 469.84 \\
\hline 8,900 & 16.931 & 0.063 & 611.27 & 614.21 \\
\hline 9,400 & 18.148 & 0.062 & 665.62 & 659.18 \\
\hline 12,600 & 24.641 & 0.064 & 875.53 & 855.97 \\
\hline 12,800 & 24.103 & 0.061 & 898.50 & 912.30 \\
\hline 13,300 & 27.600 & 0.062 & $1,012.29$ & 932.67 \\
\hline 15,200 & 30.667 & 0.062 & 1.124 .78 & $1,065.91$ \\
\hline 16,800 & 35.429 & 0.063 & $1,278.82$ & 1.159 .41 \\
\hline 19,000 & 41.870 & 0.064 & $1,487.69$ & $1,290.75$ \\
\hline 30,000 & 55.111 & 0.058 & $2,160.68$ & $2,248.81$ \\
\hline
\end{tabular}


字を示しており, 気密度の 高いとこうでは近の結果を 示している。

僅かではあるが理論值と 実測值の間に差が生ずる原 因として次のようなことが 考えられる。

a) エミルグライナーに 拉ける王力差の時間的変化 を指数関数でなく直線的に 変化するという近似的な方 法を用いたこと。

b) ガーレー測定器の測 定範囲は 2 1800 sec/100 cc と定められて抢り7)，それ 以上の高気密紙の測定では 誤差が多くなること。

ii） ショッパーとガーレ 一扮よびェミルグラ イナーの関係

ショッパーの值を規準にし, ガーレーの実測值およ び (27) 式より求めた理論值,さらにェミルグライナ 一の実測値と (28) (24) 式より求めた理論值を第 2 表 および第 7 ，第 8 図に示した。

これらの結果から理論值と実測值が非常に良く一致 していることが認められる。特にショッパーとガーレ

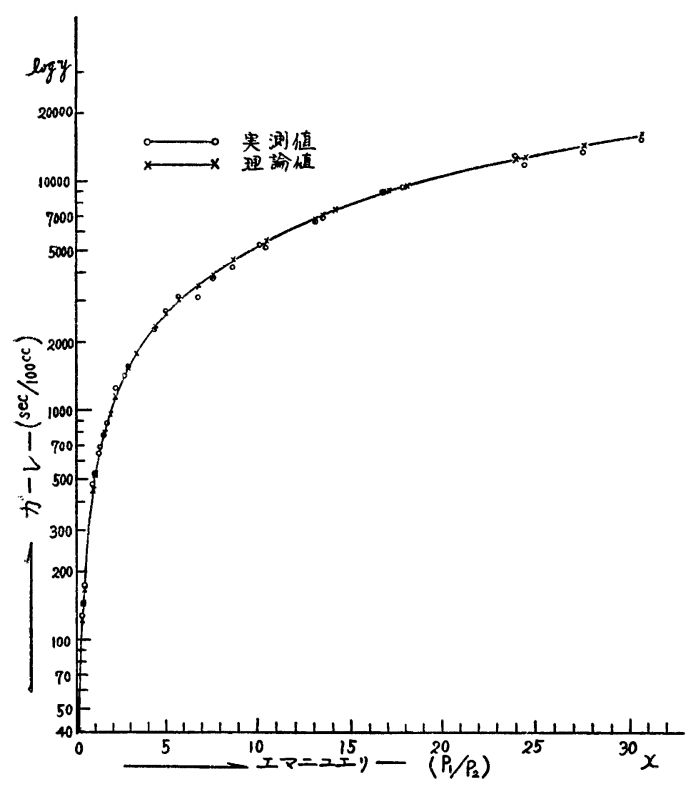

第 9 図 ガーレーエエマニニリーの

実測値と理論值の比較 一の関係は，エミルグライナーとガーレーの関係より も良く一致している。ショッパー測定器は透気度の大 小にかかわらず測定器内の減王度が常に $-100 \mathrm{~mm}$ と 一定であることが第一の原因であるら。

iii） エマニュエリーとガーレーの関係 エマニュェリー测定器に批る压力比 $P_{1} / P_{2}$ を (34) 式に入礼て求めたエマニェエリーの実測值とガ ーレーの実测值および (35) 式より求めた理論值を第 3 表拉よび第 9 㘠に示した。こ机らの結果から明らか のように，雨者の関係恃理論的にも実験的にも非常に よく一致している。第 10 図は（33）式より，厚さ $d$ をパラメータとしてガーレーとエマニニニリーの関係 を示したものである。

\section{III 空気マイクロメータを応用した透気度 試験器}

空気マイクロメータを応用した国㯆試験器として, スムースターと王研式の 2 台を取りあげてみた。両試 験器の特徵测定が迅速に完了することに峁り，スム 一スターが真空式であるのに対し, 王矿式は低圧噴出 式であることが根本的な相違点である。本試験器のス タートはどちらかと言えば平滑度の测定が主目的であ

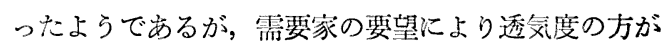
ふ总って充実して来たよらである。現在では高父密度 测定用には特殊なクランプ式ヘッドも製作されたので ここに特に透気度の高い紲を主眼として，潰の迅速 性, 精度および彷来の透気度試験器との関係について 
（1）実 験 方 法

i) スムースター

略図を第 11 図に示した。真空ポンプで空気を吸引 すると試料を通してのみ空気が浸入するようになって いる。ヘッドと絞りの間の管内圧力は試料の透気度に

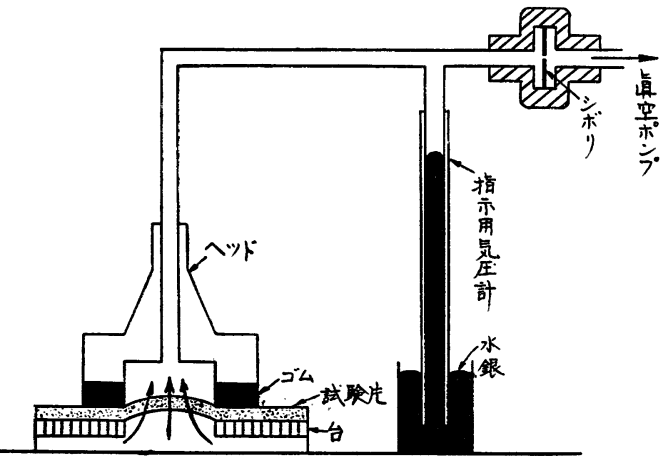

第11図 スムースターの原理㘠

検討した。

比例するので，この圧力をマノメータで読めば透気度 を知ることが出来る。指示值として絶対圧力を採用し ており，恒圧源として大気圧を利用しているのでスケ 一ルは上下に移動でき，大気圧変化に対灾できるよう にしてある。またマノメータは単管型であるからスケ ールを縮尺 $(740 / 760)$ で目盛って基準面の変化を消去 するようにしてある。

従来の透気度試験器との関係としては，ガーレーお よびェミルグライナーについて実験的に求めた。

ii）王研式透気度試験器

略図を第 12 図に示した。高压の空気を定王装管を 通して水柱約 $1 \mathrm{~m}$ 程度の圧力にして上方の管から供給 する。第 1 室はその下からパイプが出て水槽に入って いるので，この部屋の空気生はこの水柱の高さに等し い圧力で一定に調節される。第 1 室と第 2 室は毛細標

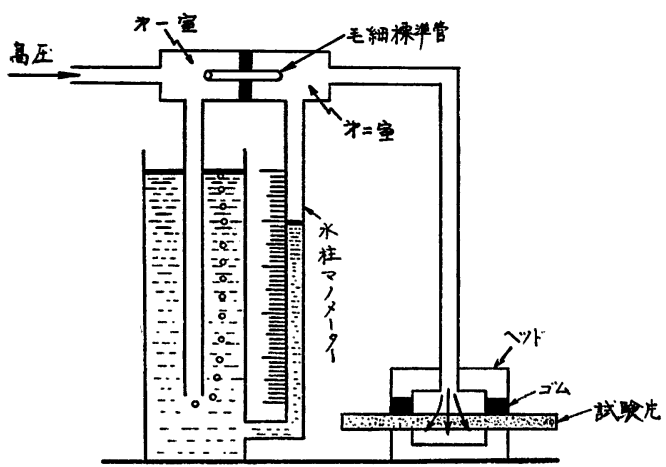

第12図王妍式透気度試験器の原理図
準管でつながっており，第 2 室は水柱マノメータと試 料挿入のへッドにつながっている。この装蚝で父密度 の高い紙を測定すると第 2 室の筀気在は上がり，マノ メータ内の水面は押し下げられる。気密度の高い紙で は第 2 室の王力は低下し水柱は上方に上がってくる。 測定にあたっては，左力指示 $0.08 \mathrm{~kg} / \mathrm{cm}^{2}$ およびマ ノメータの雺点が合っているのを確めた後, ヘッドの 下に試験片を挿入し，ハンドルを右に迴して締めれば マノメータの水面は直らに下がり始める。静止した位 置のスケールの読みが「ガーレー: 秒数をあらわす。

従来の透気度試験器との関係としては：ガーレーお よびェミルクライナーについて実駼的に求めた。

\section{(2) 実験結果および考察}

スムースターとエミルグライナーおよびガーレーと の関係を夫々第 13 図および第 14 図に示した。

第 12 図に尔いて，エミルクライナーで 0 〜 35cc/5分 の範囲では直線的な関係を示しているが，それ以上は 曲線になっている。これはシボりの直径を $0.35 \mathrm{~mm}$ 程 度にすれば直線になると考えられるが，シボりを余り 小さくすると空気流動のバランスがとれなくなり誤差 が大きくなるのと同時に，測定に長時間を要する結果 となるので思わしくない。

王研式透気度試験器とエミルグライナーおよびガー レーの関係を夫々第 15 図および第 16 図に示した。雨 図ともに非常に公範囲に直線関係が得られたが，この 理由としてはノズルに毛細管を使用し，紐管内の流れ。

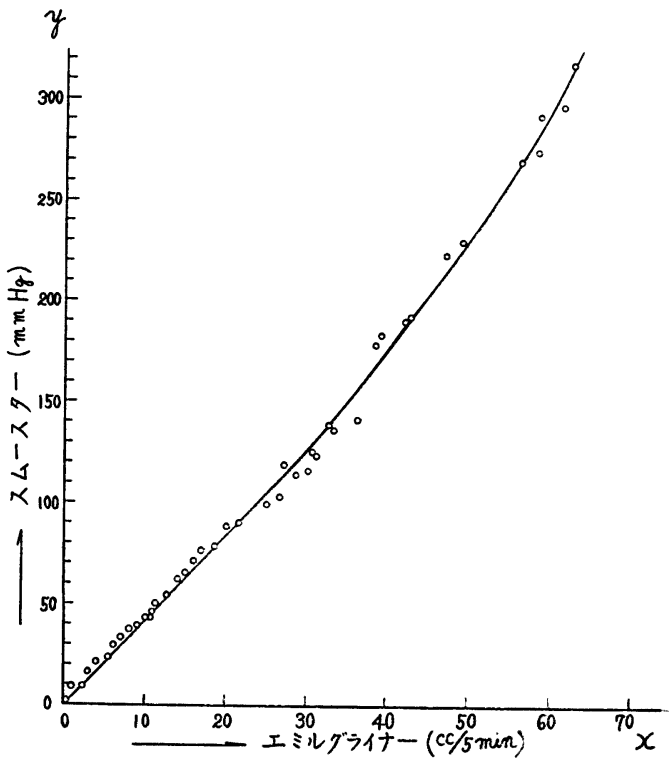

第13図 エミルグライナーとスムースターの関係 (但しスムースター，クランブ式) 


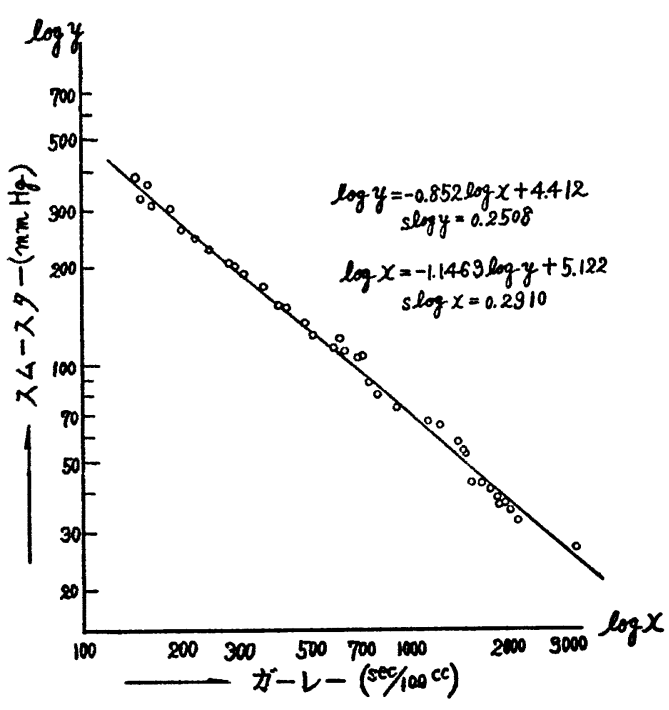

第14図ガーレーとスムースターの回㷌直線

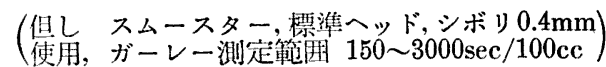

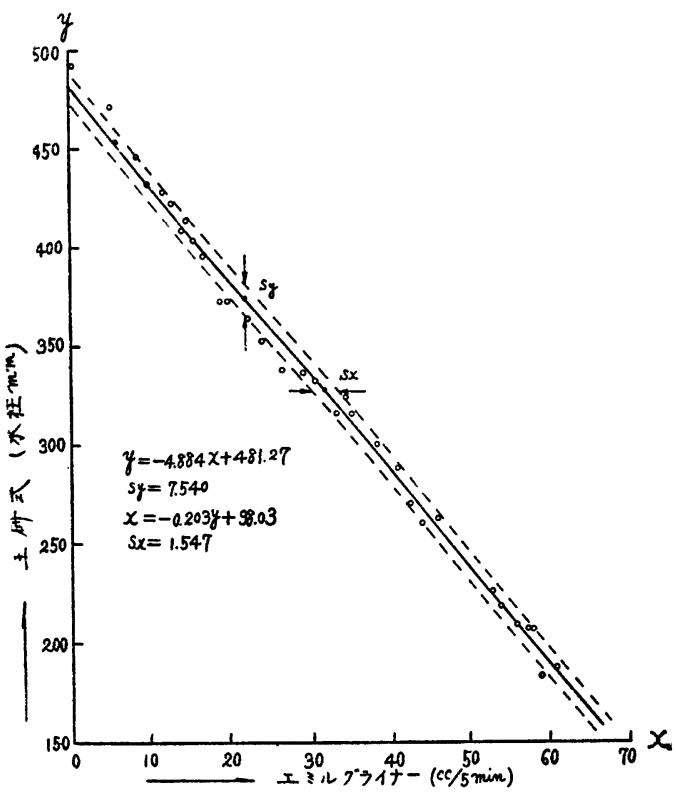

第15図エミルグライナーと王研式の回㷌直線 (但し、王研式，シボリ $0.2 \mathrm{~mm}$ 使用，测定範 $)$ を整流にし，目盛の一樣性をはかったためと思われる。 この結果から，徒来エミルグライナーで测定に5 分 間を要したもの，またガーレー值に换算して約 50000 $\sec / 100 \mathrm{cc}$ 程度のものが, 約 1 分程度で測定可能であ ることが明らかになった。

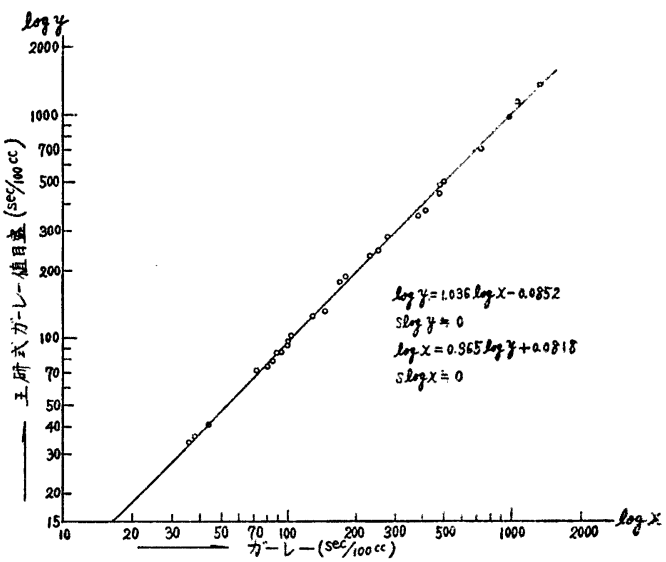

第 16 図 ガーレーと王研式気密度の回㷌直線

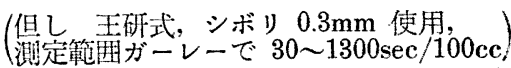

\section{IV 気密度標準片について}

本報に执いても, 测定器間の関係を求めるのにやを なく紙を用いたが，金属毛紐管を用いる方が望ましい のは当然である。

\section{（1）標準片の作彆方法}

毛細管としては長さおよび内径の異なる日金毛紐管

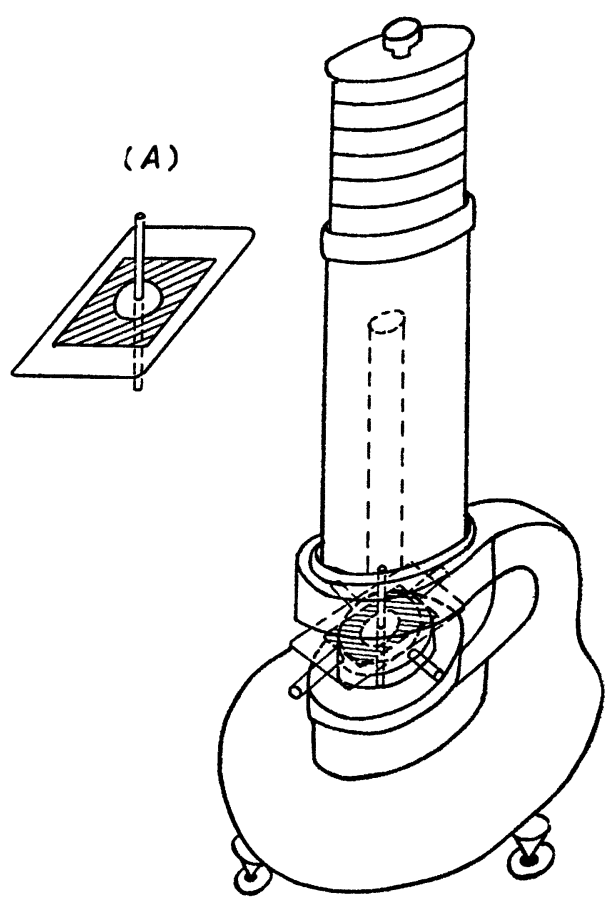

(B)

第17図 B型ガーレーと椯準片 
およびステンレス毛細管を使用した。すなわち内径は $1 / 2,1 / 3,1 / 4,1 / 5 \mathrm{~mm}$ の 4 段階，長さは 1 3 cm まで の5段階とした。

毛細管中にピアノ線を通し，外周に鋭利な邓物で傷 をつけ，少し曲げて切断した後仕上する。一方，薄い 樹脂板または金属板を大ささ約 $45 \times 80 \mathrm{~mm}$ に切り， 第 17 図 (A)のように中央部に直径 $1 \mathrm{~mm}$ 以下の孔をあ 计，其処に毛細管を入れて接着する。陚験器に挿入乙 た場合の空気洩れを防止与るため，上下雨面にゴムパ ッキンを添付する。

\section{（2）測 定 方 法}

第 17 図 (B) 住B型に標準片をセットした整の斜面図 である。

B 型の場合：毛細管が長い場合にはそのままで入ら ないので，外筒を左に迴し標泎片が容易に入るまで間 隔をあけた後，紙試料の場合と同様にセットして測定 する。

$\mathrm{A}$ 型の場合：2 個のナットを外し，上ぶたを取りガ スケット上に下部パッキンを当て，毛細管部が中心に なるよらセットして上部パッキンを当て，上ぶたの 2 個のナットで均一に締め紙の場合と同様に測定する。

以上A，Bいずれの型においても测定方法は非常に 簡単であるが慗準片検討の際は主としてB型を使用し た。

\section{（3）実験結果および考察}

ガーレーで測定して 20 秒から 1000 秒程度までの間 にある各種の標準片を作り，その再現性を検討したと ころ極めて良好であった。10回ずつ测定した時の母 平均の $95 \%$ 信頼限界を第 3 表に示した。

次に問題になるのは標準片の経年変化である。標準

第 4 表 標準片の再現性（単位：秒/100cc）

\begin{tabular}{|c|r|c|}
\hline 種 別 & 平均值 $(\mu)$ & 母平均の $95 \%$ 信頼限界 \\
\hline A & 37.9 & $37.66<\mu<38.14$ \\
B & 135.9 & $135.47<"<<136.33$ \\
C & 368.9 & $368.24<"$ " $<369.56$ \\
D & 598.7 & $596.31<" \prime<601.08$ \\
E & 932.5 & $928.82<"<<36.18$ \\
\hline
\end{tabular}

第 5 表 橴準片の経年変化

\begin{tabular}{|c|c|c|c|c|c|}
\hline 種别 & 0 & 0.5 & 1 & 1.5 & 1.66 \\
\hline A & 37.9 & 37.8 & 38.0 & 37.9 & 37.8 \\
\hline $\mathbf{F}$ & 141.0 & 140.0 & 139.5 & 140.5 & 141.0 \\
\hline G & 360.0 & 359.0 & 359.0 & 357.5 & 358.0 \\
\hline $\mathbf{H}$ & 586.0 & 588.0 & 585.0 & 584.0 & 585.5 \\
\hline I & 873.0 & 870.5 & 871.0 & 869.6 & 870.4 \\
\hline
\end{tabular}

片を最初製作したのが 35 年 4 月であり，それ以後， 6 力月毎に 36 年 12 月まで測定し, 結果を第 4 表に示 した。この結果から 1 年 8 カ月までの間では変化が認 められないと言うことが出来る。

標準片の取扱に関して特に注意を要するのは，毛紐 管中にホコリまたはゴミが入らないよう保存時に注意 する。測定前にエヤーガンなどで一旦ホコリを除去す れば最も理想的であるが，通常はきれいなピアノ線を 通してや机よい。

\section{$\mathrm{V}$ 総括}

ガーレーデンソメータ，エミルクライーポロシティ ータ, ショッパー式透気度試駼器，エマニニエリーポ ロシテメータ, 王研式透父度試験器およびスムースタ 一なぞ 6 種類の試験器について，それぞれの測定法な らびに各测定器間の関係を理論值と実測值の両面から 検討した。

(1) ガーレー $(G)$ とエミルクライナー $(E)$ の 実測值と理論值とはよく一致しているぶ，気密度の低 いところではエミルグライナーの実測値は理諭値より も小さい数字を示しており，旒密度の高いところでは その逆である。またその関係は次の 2 つの理論式によ って表わされる。

$$
\begin{aligned}
& V_{e}=\frac{83046.6}{0.803 t_{G}+513.34} \\
& V_{E}=\frac{\left(979+0.675 V_{e}\right) V_{e}}{1033}
\end{aligned}
$$

(2) ショッパー（S）とガーレーおよびエミルクラ イナーにおける理論值と奏测值の関係は非常に良く一 致しており，特にショッパーとガーレーの関係はエミ ルグライナーとガーレーの関係よりも良く一致してい る。ショッパーとガーレーは次の式によって表わされ る。

$$
t_{G}=\frac{24096.38}{V_{S}}
$$

（3）エマニュエリー（M）とガーレーに晾将る理 論値と実測値の関係も非常に良く一致しており，次の 関係が成立する。

$$
\begin{aligned}
& A_{M}=43.478 \times t_{G} / d \\
& t_{G}=523.023 \times P_{1} / P_{2}
\end{aligned}
$$

(4) スムースター $(S M)$ および主研式 $(O)$ の两 透気度試験器は共にガーレーなどの従来の試験器と密 接な関係があり，精度も優れており，特に迅速に湘定 出来るので高気密度䋊の工程検査用として優れたもの である。

ガーレーとスムースターの関係は次の 2 つ式で表 わされる。 
$d=0.4 \phi \quad$ 標準ヘッド使用の場合

$\log H_{S M}=-1.146 \log t_{G}+5.122$

$d=0.4 \phi$ クランプ式へッド使用の場合

$\log H_{S M}=-0.638 \log t_{G}+4.247$

但し $d=$ オリイスの径

次にガーレーと王研式の関係は次の実験式で表わさ れる。 $d=0.3 \phi \quad L=30 \mathrm{~mm}$ の場合

$\log T_{o}=0.965 \log t_{G}+0.0818$

但し $d=$ 毛細管内径

（5）透気度試験器の精度および器差の検定などの 標準試料として，大抵の場合紙が用いられて来たが， これにはいろいると問題があるので，金属毛細管をも った標準板を作製したところ，10１300 sec/100 cc の 範团内では再現性が良好で，かつ経年変化も現在まで 約 2 年間変化のないものが得られた。

\section{引用文献}

1) J. P. Casey; "Pulp and Paper" Vol. III $1281 \mathrm{p}$ (1961) New York

2) 木村, 寺谷; 木材研究 No.16 70 (昭 31)

3) W. Dieterle, Basel ; Bull. Schweiz. Elek. Vereins, Nr. 13. 3. (1960)

4）松下, 渡辺; “紙パルプ技術の友” Vol. X 8p (1959)

5) K. G. Chesley, E. D. Jones, and R. L. Jruax ; Tappi 42. 299 (1959)

6) JIS C 2111 (電気絶縁紙試験方法) $8 \mathrm{p}-1960$

7) JIS P 8117

\section{文献 抄 録 (578頁より)}

\section{○イオン交換法によるアンモニウムベース賈硫酸廃液} からのアンモニアの回収

W. R. Effer, E. W. Hopper and H. B. Marshall:

P. P. M. C 62 No. 10. (Oct. 1961) p. T-447-454 $\mathrm{NH}_{3}$ ベース SP 廃液を強酸型陽イオン交換樹脂に通

して $\mathrm{NH}_{3}$ を吸着させ, $\mathrm{SO}_{2}$ 溶液で溶離回収する方法 についての研究である。

回収效率は $\mathrm{NH}_{3}$ 以外の多価カチオンによって恶影

響を受けるが，これを除去するため 2 系列の樹脂を用 い, 第 1 のカラム(A)で多体カチオンを除去し, 第 2 の カラム(B)で $\mathrm{NH}_{3}$ を吸着する方法を採った。(A)の再生 にはリグニンスルホン酸及び $\mathrm{NH}_{4} \mathrm{HSO}_{3}$ 溶液を用い たが，後者がより有効であった。(B)の再生には $\mathrm{SO}_{2}$ 溶液を用いその流出液は蒸解原液として用いる。回収 効率は $\mathrm{SO}_{2}$ 溶液の量, 漶度, 温度により異なるが, 68.5\%から $82.7 \%$ であった。

この方法の長所は, 蒸発, 燃㮦工程を必要とせず, 設備が簡単であり, 特別の薬品を必要とせ奴点であり, 通常の SP 工場に容易に応用できる。 $\mathrm{NaHSO}_{3}$ 溶液を 用いれば $\mathrm{Na}$ ベース廃液の回収にも応用できる。
樹脂を連続使用すると交換容量は若干低下するが， 弱い酸化処理によって殆んど回復させ得る。

(名井 博)

\section{○二酸化塩素生成法における最近の傾向}

J. F. Serafin and H. C. Scribner: Pulp and Paper Mag. Can.: 62 No. 10 T-473 (Oct. 1961) $\mathrm{ClO}_{2}$ 製造法関する Mathieson 法と ER-2 法につ いての最近の進歩について比較検討を行なっている。 副成して来る流出排液中の 硫酸以外の成分, 即ち $\mathrm{Na}_{2} \mathrm{SO}_{4}$ 及び $\mathrm{Cl}_{2}$ を，別们用することの出来るよ うな KP 工場の場合, ER-2法の方が, Mathieson法 よりも, $\mathrm{ClO}_{2} 1 \mathrm{lb}$ 当り $1.3 \mathrm{c}$ のコスト高になる。但し, これは, Mathieson 法に批りる $\mathrm{ClO}_{2}$ 收率省 $90 \%$ 之 して計算したものである。実際には，多くの工場では 90\%以下の収率で運転しているので，このような処で は，ER-2法の方が経済的汇魅力がある。特に，排液 中の硫酸をる利用出来るような工場汇执いては，な扮 更である。大量の $\mathrm{ClO}_{2}$ の製造を必要とする工場に おいては，ER-2法の方が，設㣁資金が少なくて済む。 更に，反忘が上り簡単な上，大した間題なくオートメ ーション出来ると言う利点が ER-2 法には有の。 (续藤 算) 